\title{
The Effect of Different Rates of Biochar and Biochar in Combination with N Fertilizer on the Parameters of Soil Organic Matter and Soil Structure
}

\author{
Martin Juriga', Vladimír Šimanský'*, Ján Horák², Elena Kondrlová2, \\ Dušan Igaz², Nora Polláková', Natalya Buchkina ${ }^{3}$, Eugene Balashov ${ }^{3}$
}

1 Department of Soil Science, Faculty of Agrobiology and Food Resources, Slovak University of Agriculture, Tr. A. Hlinku 2, 94976 Nitra, Slovakia

2 Department of Biometeorology and Hydrology, Horticulture and Landscape Engineering Faculty, Slovak University of Agriculture, Hospodárska 7, 94901 Nitra, Slovakia

3 Agrophysical Research Institute, 14 Grazhdansky prospekt, St. Petersburg, 195220, Russia

* Corresponding author's e-mail: vladimir.simansky@uniag.sk

\begin{abstract}
Since biochar is considered to be a significant source of carbon, in this work we have evaluated the changes in soil organic matter (SOM) and soil structure due to application of biochar and biochar with $\mathrm{N}$ fertilization, and have considered the interrelationships between the SOM parameters and the soil structure. The soil samples were collected from Haplic Luvisol at the locality of Dolná Malanta (Slovakia) during 2017. The field experiment included three rates of biochar application (B0 - no biochar, B10 - biochar at the rate of $10 \mathrm{tha}^{-1}$, B20 - biochar at the rate of $20 \mathrm{t} \mathrm{ha}^{-1}$ ) and three levels of $\mathrm{N}$ fertilization ( $\mathrm{N} 0$ - no nitrogen, $\mathrm{N} 160$ - nitrogen at the rate of $160 \mathrm{~kg} \mathrm{ha}^{-1}$, $\mathrm{N} 240$ - nitrogen at the rate of $240 \mathrm{~kg} \mathrm{ha}^{-1}$ ). The rate of biochar at $20 \mathrm{tha}^{-1}$ caused an increase in the organic carbon $\left(\mathrm{C}_{\text {org }}\right)$ content. The combination of both rates of biochar with 160 and $240 \mathrm{~kg} \mathrm{~N} \mathrm{ha}^{-1}$ also caused an increase in $\mathrm{C}_{\text {org. }}$. In the case of B20 the extractability of humic substances carbon $\left(\mathrm{C}_{\mathrm{HS}}\right)$ was $17.79 \%$ lower than at $\mathrm{B} 0$. A significant drop was also observed in the values of the extraction of humic acids carbon $\left(\mathrm{C}_{\mathrm{HA}}\right)$ and fulvic acids carbon $\left(\mathrm{C}_{\mathrm{FA}}\right)$ after the addition of biochar at a dose of $20 \mathrm{t} \mathrm{ha}^{-1}$ with $160 \mathrm{~kg} \mathrm{~N} \mathrm{ha}^{-1}$. However, both rates of biochar had a significant effect at $240 \mathrm{~kg} \mathrm{~N} \mathrm{ha}^{-1}$. After application of $20 \mathrm{t} \mathrm{ha}^{-1}$ of biochar the content of water-stable macro-aggregates (WSA ${ }_{\text {ma }}$ ) significantly increased compared to control. This rate of biochar also increased the mean weight diameter $\left(\mathrm{MWD}_{\mathrm{W}}\right)$ and the index of water-stable aggregates $(\mathrm{Sw})$ and decreased the coefficient of vulnerability $(\mathrm{Kv})$. The biochar at a rate of $20 \mathrm{tha}^{-1}$ with $240 \mathrm{~kg} \mathrm{~N}^{-1}$ the value of $\mathrm{MWD}_{\mathrm{W}}$ increased and value of $\mathrm{Kv}$ decreased significantly. The contents of $\mathrm{C}_{\text {org }}$ and $\mathrm{C}_{\mathrm{L}}$ correlated positively with $\mathrm{WSA}_{\mathrm{ma}}, \mathrm{MWD}_{\mathrm{W}}$ and $\mathrm{Sw}$ and negatively with WSA $\mathrm{W}_{\mathrm{mi}}$ and $\mathrm{Kv}$. The extraction of $\mathrm{C}_{\mathrm{HA}}$ and $\mathrm{C}_{\mathrm{FA}}$ was in negative relationship with $\mathrm{MWD}_{\mathrm{W}}$. We conclude that the application of biochar and biochar combined with $\mathrm{N}$ fertilizer had a positive influence on SOM and soil structure.
\end{abstract}

Keywords: biochar; soil organic matter; soil structure; nitrogen fertilizer

\section{INTRODUCTION}

Soil structure is one of the most important soil properties. It is defined as a spatial arrangement of soil particles with pores among them [Odes 1993]. According to Blanda et al. [2014] soil aggregates are basic soil structural units that control the dynamics of soil organic matter (SOM) and influence the soil's ability to sequestrate and stabilize organic carbon. Conceptually, aggregates are generally classified into macro- aggregates $(>0.25 \mathrm{~mm})$ and micro-aggregates $(<0.25 \mathrm{~mm})$ [Six et al. 2000]. The stability of soil aggregates is one of the most important elements of soil protection and conservation of its functions. Soil resistance to erosive agents and compaction increases with improvement of aggregate stability [Chaplot and Cooper 2015]. Aggregation is the result of reorganisation, flocculation and cementation of soil particles. As reported by Bronick and Lal [2005], aggregation is influenced by a number of factors. First example is when oxides of iron and 
aluminium can act as inorganic binders and second is when extracts of roots, fungal hyphae, bacteria and soil fauna are considered as cementing agents which connect soil particles into stable macro-aggregates [Odes 1993, Tisdall 1996].

SOM is the most important indicator of soil quality because of its effects on wide range of soil particles. It is considered to be a key element in the stabilization of soil aggregates. The dynamic of SOM is related to the formation and destruction of macro-aggregates. Soil aggregates control the dynamics of SOM [Six et al. 2000] which is the main source of soil organic carbon (SOC). SOC improves aggregation by bonding soil particles together and its effect depends on the rate of its decomposition. The intensification of agriculture has led to a significant decrease of organic matter content in agricultural soils in the last decades of the twentieth century. It has deteriorated the soil structure and the soil fertility [Bossuyt et al. 2004]. The ways how to enhance the stock of SOM or SOC in arable soils, are still being researched [Sainju et al. 2009]. A good option to increase carbon sequestration in the soil is production and application of biochar. The intentional and unintentional addition of biochar into soils, known as „Terra preta,“ has promoted soil fertility. These soils are among the most significant examples of biochar enriched soils by humans [Wang et al. 2016].

Biochar is a solid, C-rich product [Fisher and Glaser 2012] that arises during the thermal decomposition of different organic material in conditions with low or no oxygen. The properties of biochar mainly depend on the type of material used for its production and on the temperature of pyrolysis [Ahamd et al. 2014, Zlielinska et al. 2015]. Firstly, the biochar produced from manure usually has smaller surface area, than biochar produced from wood. Secondly, the higher temperature increases the content of carbon in biochar while the content of oxygen and hydrogen decreases. Biochar has the potential to enhance the chemical, physical and biological properties of soil [Hussian et al. 2016]. The addition of biochar can increase cation exchange capacity (CEC) and $\mathrm{pH}$. Biochar can absorb nutrients but also heavy metals due to its high porosity and the presence of carboxyl and hydroxyl groups [Glaser et al. 2002, Joseph 2009]. In addition, biochar can increase soil porosity, reduced soil bulk density and improve soil retention capacity [Abel et al. 2013, Omondi et al. 2016]. The increase of soil aggregate stability and the content of macro-aggregates have been shown in several studies [Zhang et al. 2015, Liu et al. 2014, Sun and Lu 2014].

Since biochar is material rich in $\mathrm{C}$ we expected that its application would increase the content of labile $\mathrm{C}$ in soil and the increase will correlate with the application rate of biochar which would also improve the condition of soil structure. The aim of this study was to evaluate: (i) the effects of different rates of biochar and biochar with $\mathrm{N}$ fertilizer on the parameters of soil organic matter, (ii) the parameters of the soil structure, (iii) the inter-relationships between measured parameters of the soil organic matter and the soil structure affected by biochar and biochar with $\mathrm{N}$.

\section{MATERIAL AND METHODS}

\section{The characteristics of the territory}

The study was carried out at the experimental site of Slovak University of Agriculture in the Nitra region of Slovakia (Dolná Malanta, lat. $48^{\circ} 10^{\circ} 00^{\prime \prime}$, lon. $\left.18^{\circ} 19^{\circ} 00^{\circ}\right)$. The area is located about $4 \mathrm{~km}$ from Nitra and it has flat terrain properties with a slight southwestern slope. From a geological point of view, the territory is located on the geological boundary of the mountain range of Tribeč and Danubian Lowland with an altitude 175-180 m a.s.l. The soil is classified as Haplic Luvisol and it has neutral $\mathrm{pH}$ (6.69). The territory is located in a warm agro-climatic zone with a mean annual air temperature of $10.2^{\circ} \mathrm{C}$. The mean total annual rainfall is $539 \mathrm{~mm}$.

\section{The description of the experiment}

The experiment was established in March 2014 . The crop rotation consisted of spring barley (2014), corn (2015), spring wheat (2016) and corn (2017). In 2017 following treatments were used: 1 . B0 - without biochar, 2. B10 -10 $\mathrm{t} \mathrm{ha}^{-1}$ of biochar, 3. B20 - $20 \mathrm{t} \mathrm{ha}^{-1}$ of biochar, 4 . B0N160 - without biochar but with $160 \mathrm{~kg} \mathrm{~N} \mathrm{ha}^{-1}$, 5. B10N160 - $10 \mathrm{tha}^{-1}$ of biochar and $160 \mathrm{~kg} \mathrm{~N}$ ha $^{-1}$, 6. B20N160 - $20 \mathrm{t} \mathrm{ha}^{-1}$ of biochar and 160 $\mathrm{kg} \mathrm{N} \mathrm{ha}{ }^{-1}, 7$. B0N240 - without biochar but with $240 \mathrm{~kg} \mathrm{~N} \mathrm{ha}^{-1}$, 8. B10N240 - $10 \mathrm{t} \mathrm{ha}^{-1}$ of biochar and $240 \mathrm{~kg} \mathrm{~N} \mathrm{ha}^{-1}, 9$. B20N240 - $20 \mathrm{t} \mathrm{ha}^{-1}$ of biochar and $240 \mathrm{~kg} \mathrm{~N} \mathrm{ha}^{-1}$. The LAD 27 was used as $\mathrm{N}$ fertilizer. The used biochar was made of grain husks and paper sludge at a ratio of 1:1 at the temperature of $500{ }^{\circ} \mathrm{C}$. The composition of the biochar and its properties are shown in Table 1 . 
Table 1. Basic composition and properties of applied biochar

\begin{tabular}{|c|c|}
\hline $\mathrm{Ca}$ & $57 \mathrm{~g} \mathrm{~kg}^{-1}$ \\
\hline $\mathrm{Mg}$ & $3,9 \mathrm{~g} \mathrm{~kg}^{-1}$ \\
\hline $\mathrm{K}$ & $15 \mathrm{~g} \mathrm{~kg}^{-1}$ \\
\hline $\mathrm{N}$ & $0.7 \mathrm{~g} \mathrm{~kg}^{-1}$ \\
\hline Total C & $53.1 \%$ \\
\hline Total N & $1.4 \%$ \\
\hline Ash & $38.3 \%$ \\
\hline $\mathrm{pH}$ & 8.8 \\
\hline Size of biochar & $1-5 \mathrm{~mm}^{-1}$ \\
\hline Surface area & $21.7 \mathrm{~m}^{-2} \mathrm{~g}^{-1}$ \\
\hline
\end{tabular}

\section{The collection of samples and analytical methods}

The soil samples were collected in 2017 at monthly intervals from the beginning (April) to the end (September) of the corn growing season (from $38^{\text {th }}$ to $43^{\text {rd }}$ month since biochar application). The soil samples were collected from the depth 0-30 $\mathrm{cm}$. Subsequently, roots and other large parts of plants were removed from the samples, they were transferred to the laboratory and air dried at room temperature. The fallowing parameters of soil organic matter and soil structure were evaluated:

- content of water-stable macro- (WSA ma) and micro-aggregates $\left(\mathrm{WSA}_{\mathrm{mi}}\right.$ ) (fractions: $>5 \mathrm{~mm}$, 5-3 mm, 3-2 mm, 2-1 mm, 1-0.5 mm, $0,5-0.25 \mathrm{~mm}$ a $<0.25 \mathrm{~mm}$ ) by Bachsayev's method [Hraško et al. 1962],

- mean weight diameter of macro-aggregates (MWDd), which was calculated from the percentage representation of individual fractions of structural macro-aggregates obtained by sifting through a set of sieves:

$$
M W D_{d}=\sum_{i=1}^{n} x_{i} w_{i}
$$

where:

$i-1,2,3 \ldots . \mathrm{n}$ - corresponds to each determined fraction

$x i$ - weighted average of the size fraction $w i$ - percentage of sample on sieve,

- mean weight diameter of water-resistant macro-aggregates $\left(\mathrm{MWD}_{\mathrm{w}}\right)$, which was calculated from the percentage of the individual fraction of water-resistant macro-aggregates obtained by sifting through a set of sieves in distilled water:

$$
M W D_{W}=\sum_{i=1}^{n} x_{i} W S A
$$

where:

$i-1,2,3 \ldots . \mathrm{n}$ a- corresponds to each determined fraction

$x i$ - weighted average fraction size $(\mathrm{mm})$

$W S A$ - water-resistant aggregates,

- coefficient of vulnerability (Kv) [Valla et al. 2000] according to the equation:

$$
K_{v}=\frac{M W D_{d}}{M W D_{w}}
$$

- index of water-resistant macro-aggregates $(\mathrm{Sw})$ was calculated based on the grain composition and the percentage representation of water-resistant macro-aggregates:

$$
S w=\frac{W S A-0.09 \text { sand }}{\text { silt }+ \text { clay }}
$$

where:

WSA - \% content of water-resistant aggregates,

- content of total organic carbon $\left(\mathrm{C}_{\text {org }}\right)$ was determined oxidometrically [Dzadowiec and Gonet 1999a],

- content of labile carbon $\left(\mathrm{C}_{\mathrm{L}}\right)$ [Loginow et al. 1987],

- group composition of humic substances [Dzadowiec and Gonet 1999b],

- colour quotient of humic substances $\left(\mathrm{Q}_{\mathrm{HS}}\right)$ and colour quotient of humic acids $\left(\mathrm{Q}_{\mathrm{HA}}\right)$.

\section{Statistical analysis}

The individual parameters of organic matter and soil structure were evaluated by statistical analysis through the Statgraphic Centurion XV Program I. (Statpoint Technologies, Inc., USA) using ANOVA single-factor analysis. LSD test with a significance level of $\alpha=0.05$ was used to compare the effect of biochar and $\mathrm{N}$ fertilization. The dependence between the parameters of soil structure and soil organic matter was evaluated by the correlation matrix.

\section{RESULTS AND DISCUSSION}

Total organic carbon $\left(\mathrm{C}_{\text {org }}\right)$ is an important indicator of SOM, which is widely used in the evaluation of the total amount of organic compounds in soils [Zhang et al. 2005, Visco et al. 2005]. Due 
to its predominantly aromatic structure, biochar is a relatively stable form of C [Pasakayastha et al. 2015]. Only a small part of biochar can be mineralized in the short time after application, especially if biochar is produced at lower pyrolysis temperatures [Mukome et al. 2015]. Our results indicate that the addition of biochar in overall increased the $\mathrm{C}_{\text {org }}$ content in the soil (Fig. 1) but the increase was statistically significant (28.69\%) only with the higher biochar rate (B20) compared to the control (B0). When compared to B0N160 treatment, the content of $\mathrm{C}_{\text {org }}$ increased by $12.05 \%$ for B10N160 and by $23.59 \%$ for B20N160. Furthermore, the higher rate of biochar had stronger effect on $\mathrm{C}_{\text {org }}$ content in the soil than the lower rate of biochar (12.22\% difference in the $\mathrm{C}_{\text {org }}$ content). Soil $\mathrm{C}_{\text {org }}$ content increased also when the combination of biochar (both rates) with $240 \mathrm{~kg}$ $\mathrm{N}^{-1}$ was used. The obtained value in B10N240 was $19.20 \%$ higher, while in B20N240 - 19.51\% higher than in B0N240. The difference between the rates of biochar was not statistically significant. Similar findings have also been reported by Mavi et al. [2018] who recorded a significant $C_{\text {org }}$ increase after the application of biochar and biochar with $\mathrm{N}$, but only at higher doses of N (120 and $\left.150 \mathrm{~kg} \mathrm{ha}^{-1}\right)$. The lower rate of $\mathrm{N}\left(60 \mathrm{~kg} \mathrm{ha}^{-1}\right)$ did not notably alter the content of $\mathrm{C}_{\text {org }}$. Labile carbon $\left(\mathrm{C}_{\mathrm{L}}\right)$ is an important component of SOM and it is considered to be a sensitive indicator of soil quality [Jiang and Xu 2006]. During pyrolysis, either labile or leached organic carbon is generated. These low-weight molecular organic com- pounds directly increase the content of $\mathrm{C}_{\mathrm{L}}$ in soil. The addition of $\mathrm{N}$ into the soil reduces the content of carbon in organic matter due to a decrease of C:N ratio [Yan et al. 2007]. In conclusion, the addition of biochar alone or biochar with $\mathrm{N}$ did not have a significant effect on $\mathrm{C}_{\mathrm{L}}$ content (Fig. 2).

Humic substances (HS) are considered to be stable fractions of soil organic matter. They represent heterogeneous components consisting of large macromolecules with functional groups formed by chemical and biochemical reactions. HS play an important role not only in soil fertility but also in the sequestration of $\mathrm{C}$ [Spaccini et al. 2002]. There is still lack of information about the effect of biochar on the chemical composition of HS. However, recent studies have shown that biochar can play an important role in the formation of HS [Jindo et al. 2016]. As a result of biochar and biochar with $\mathrm{N}$ application, the reduction in humic substances carbon $\left(\mathrm{C}_{\mathrm{HS}}\right)$, humic acids carbon $\left(\mathrm{C}_{\mathrm{HA}}\right)$ and fulvic acids carbon $\left(\mathrm{C}_{\mathrm{FA}}\right)$ was observed (Table 2). Application of the higher rate of biochar resulted in the reduction of $\mathrm{C}_{\mathrm{HS}}$ content by $17.79 \%, \mathrm{C}_{\mathrm{HA}}$ - by $15.98 \%$ and $\mathrm{C}_{\mathrm{FA}}$ - by $19.69 \%$ compared to the control. After the addition of biochar with $160 \mathrm{~kg} \mathrm{~N} \mathrm{ha}^{-1}$, there was a significant decrease in $\mathrm{C}_{\mathrm{HS}}$ content by $21.87 \%, \mathrm{C}_{\mathrm{HA}}$ - by $24.46 \%$ and $\mathrm{C}_{\mathrm{FA}}$ - by $18.66 \%$ in $\mathrm{B} 20 \mathrm{~N} 160$ when compared to B0N160 treatment. But, when biochar with 240 $\mathrm{kg} \mathrm{N} \mathrm{ha}^{-1}$ was applied, the high effect was registered for both rates of biochar (B10N240 and B20N240): $\mathrm{C}_{\mathrm{HS}}$ decreased by $23.32 \%$ and $24.43 \%$, $\mathrm{C}_{\mathrm{HA}}-$ by $15.61 \%$ and $23.75 \%, \mathrm{C}_{\mathrm{FA}}-$ by $31.77 \%$

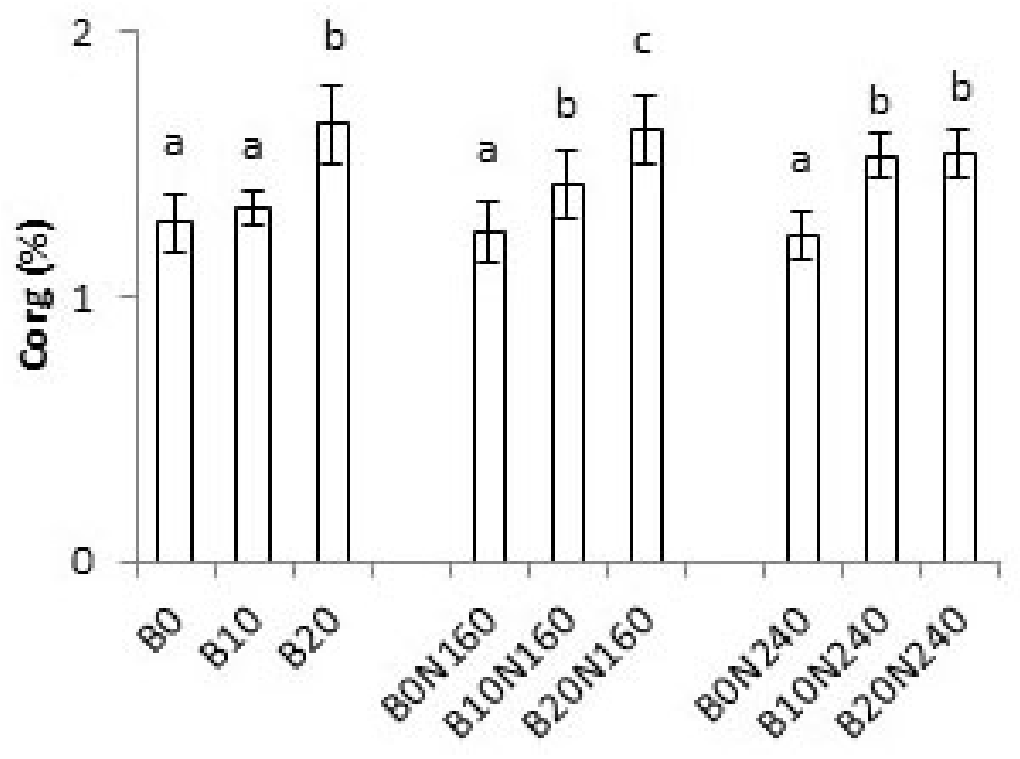

Figure 1. Contents of soil organic carbon. Treatments are stated in Material and methods. Different letters $(\mathrm{a}, \mathrm{b}, \mathrm{c})$ between columna indicate that treatment means are significantly different at $\mathrm{P}<0.05$ according to LSD test 


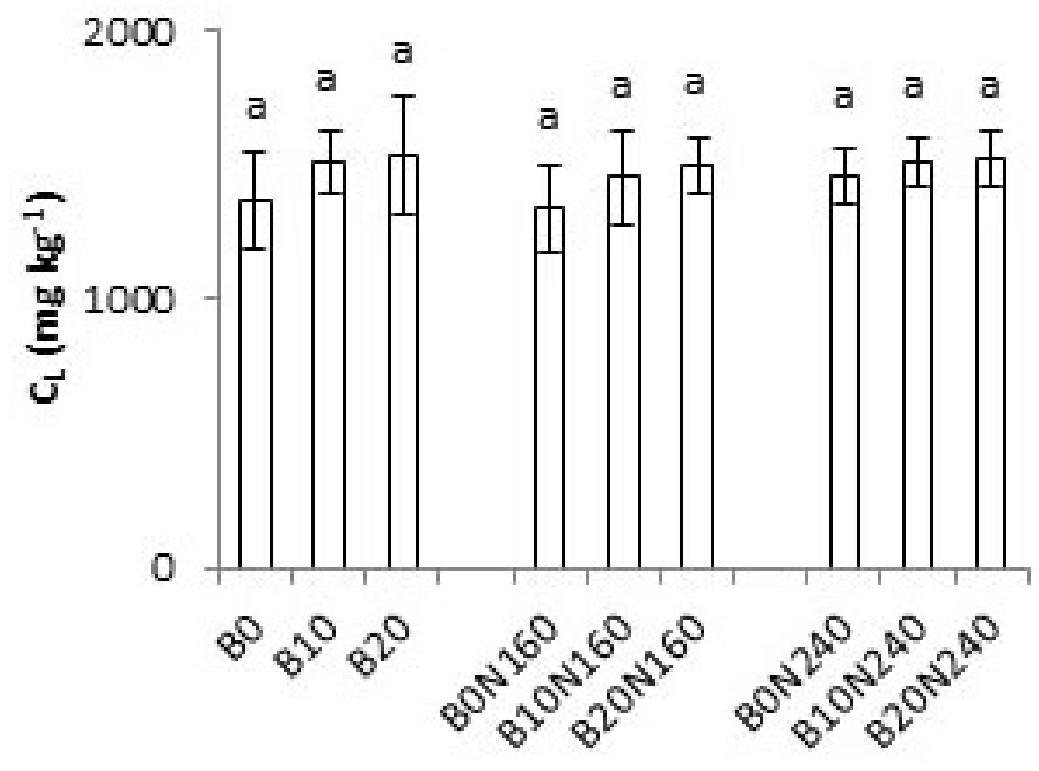

Figure 2. Contents of labile carbon. Treatments are stated in Material and methods. Different letters (a, b, c) between columns indicate that treatment means are significantly different at $\mathrm{P}<0.05$ according to LSD test

Table 2. Statistic evaluation of the parameters of soil organic matter

\begin{tabular}{|c|c|c|c|c|c|c|}
\hline \multirow{2}{*}{ Treatment } & $\mathrm{C}_{\mathrm{HS}}$ & $\mathrm{C}_{\mathrm{HA}}$ & $\mathrm{C}_{\mathrm{FA}}$ & \multirow{2}{*}{$\mathrm{C}_{\mathrm{HA}}: \mathrm{C}_{\mathrm{FA}}$} & \multirow{2}{*}{$\mathrm{Q}_{\mathrm{HS}}$} & \multirow{2}{*}{$Q_{H A}$} \\
\hline & \multicolumn{3}{|c|}{$\%$ from $\mathrm{C}_{\text {org }}$} & & & \\
\hline B0 & $36.31 \pm 1.98^{b}$ & $19.59 \pm 2.01^{b}$ & $16.73 \pm 0.87^{b}$ & $1.18 \pm 0.14^{\mathrm{a}}$ & $4.55 \pm 0.20^{\mathrm{a}}$ & $3.72 \pm 0.17^{a}$ \\
\hline B10 & $36.81 \pm 3.82^{b}$ & $19.41 \pm 1.62^{b}$ & $17.40 \pm 2.86^{b}$ & $1.14 \pm 0.17^{a}$ & $4.37 \pm 0.20^{\mathrm{a}}$ & $3.72 \pm 0.10^{\mathrm{a}}$ \\
\hline B20 & $29.85 \pm 2.73^{a}$ & $16.46 \pm 2.49^{a}$ & $13.39 \pm 1.84^{a}$ & $1.25 \pm 0.25^{\mathrm{a}}$ & $4.53 \pm 0.29^{a}$ & $3.78 \pm 0.10^{a}$ \\
\hline BoN160 & $39.65 \pm 3.45^{c}$ & $21.91 \pm 2.71^{\mathrm{b}}$ & $17.74 \pm 2.67^{b}$ & $1.27 \pm 0.27^{\mathrm{a}}$ & $4.60 \pm 0.27^{a}$ & $3.77 \pm 0.03^{a}$ \\
\hline B10N160 & $35.16 \pm 3.35^{b}$ & $19.78 \pm 2.00^{\mathrm{ab}}$ & $15.98 \pm 3.22^{\mathrm{ab}}$ & $1.25 \pm 0.31^{\mathrm{a}}$ & $4.51 \pm 0.32^{\mathrm{a}}$ & $3.80 \pm 0.13^{a}$ \\
\hline B20N160 & $30.98 \pm 2.11^{a}$ & $16.55 \pm 2.66^{a}$ & $14.43 \pm 1.91^{a}$ & $1.18 \pm 0.36^{a}$ & $4.45 \pm 0.28^{a}$ & $3.31 \pm 0.14^{a}$ \\
\hline BON240 & $42.66 \pm 3.38^{b}$ & $22.36 \pm 1.70^{\mathrm{b}}$ & $20.30 \pm 3.45^{b}$ & $1.13 \pm 0.24^{\mathrm{a}}$ & $4.70 \pm 0.30^{\mathrm{a}}$ & $3.87 \pm 0.15^{\mathrm{a}}$ \\
\hline B10N240 & $32.71 \pm 1.47^{a}$ & $18.87 \pm 1.75^{a}$ & $13.85 \pm 1.57^{a}$ & $1.39 \pm 0.27^{a}$ & $4.52 \pm 0.27^{a}$ & $3.78 \pm 0.17^{a}$ \\
\hline B20N240 & $32.24 \pm 2.58^{\mathrm{a}}$ & $17.05 \pm 2.12^{\mathrm{a}}$ & $15.19 \pm 2.57^{a}$ & $1.16 \pm 0.30^{\mathrm{a}}$ & $4.53 \pm 0.22^{\mathrm{a}}$ & $3.79 \pm 0.15^{\mathrm{a}}$ \\
\hline
\end{tabular}

Treatments are stated in Material and methods. Different letters (a, b, c) between lines indicate that treatment means are significantly different at $P<0.05$ according to LSD test.

$\mathrm{C}_{\mathrm{HS}}$ - content of humic substances carbon, $\mathrm{C}_{\mathrm{HA}}$ - content of humic acids carbon, $\mathrm{C}_{\mathrm{FA}}$ - content od fulvic acids carbon, $\mathrm{C}_{\mathrm{HA}}: \mathrm{C}_{\mathrm{FA}}-$ humic acids carbon to fulvic acids carbon ratio, $\mathrm{Q}_{\mathrm{HS}}$ - colour qutient od humic substances, $\mathrm{Q}_{\mathrm{HA}}$ - colour qoutient od humic acids

and $24.16 \%$, respectively, compared to the control (B0N240). The significant differences were also identified between the rates of biochar after the application of biochar alone, where $\mathrm{B} 20$ treatment resulted in $18.91 \%\left(\mathrm{C}_{\mathrm{HS}}\right), 16.03 \%\left(\mathrm{C}_{\mathrm{HA}}\right)$ and $23.05 \%$ $\left(\mathrm{C}_{\mathrm{FA}}\right)$ lower concentrations than $\mathrm{B} 10$. According to Zhao et al. [2017], the different effect of biochars on the content of $\mathrm{C}_{\mathrm{HA}}$ and $\mathrm{C}_{\mathrm{FA}}$ depended on the different pyrolysis temperatures during the biochar production $\left(300^{\circ} \mathrm{C}, 400^{\circ} \mathrm{C}, 500^{\circ} \mathrm{C}, 600^{\circ} \mathrm{C}\right)$. All tested types of biochar initially had a beneficial effect on $\mathrm{C}_{\mathrm{HA}}$ and $\mathrm{C}_{\mathrm{FA}}$, however after a short time a decrease of $\mathrm{C}_{\mathrm{HA}}$ and $\mathrm{C}_{\mathrm{FA}}$ was observed in the case of biochar produced at a lower temperature $\left(300^{\circ} \mathrm{C}, 400^{\circ} \mathrm{C}\right)$. An increase of soil microorganisms was stimulated by biochar application, which promoted the production of humic (HA) and fulvic acids (FA). Over time, parts of HA and FA are used by microorganisms as a result of the decline in the slightly mineralized sources of carbon. The humic acids carbon to fulvic acids carbon ratio $\left(\mathrm{C}_{\mathrm{HA}}: \mathrm{C}_{\mathrm{FA}}\right)$ is the next of evaluated qualitative parameter of humus. The values greater that 1 characterise fertile soils [Rudkowska and Pikula 2013]. There was no any significant changes in $\mathrm{C}_{\mathrm{HA}}: \mathrm{C}_{\mathrm{FA}}$, colour quotient of humic substances $\left(\mathrm{Q}_{\mathrm{HS}}\right)$ and colour quotient of humic acids $\left(\mathrm{Q}_{\mathrm{HA}}\right)$ after the application of biochar or biochar with $\mathrm{N}$ (Table 2). 
The average values of the soil structure parameters for the corn growing season [2017] are shown in Table 3. When evaluating the soil structure, the one of the most important parameters is content of water-stable macro-aggregates ( $\mathrm{WSA}_{\mathrm{ma}}$ ). It represents the individual size groups of aggregates and their water resistance [Scott, 2000]. We concluded that the application of biochar and biochar in combination with $\mathrm{N}$ fertilizer had a positive effect on the $\mathrm{WSA}_{\mathrm{ma}}$ content. It increased with the application of biochar in the order $\mathrm{B} 0<\mathrm{B} 10<\mathrm{B} 20$. The application of biochar alone at a dose of $20 \mathrm{tha}^{-1}$ (B20) significantly increased the content of $\mathrm{WSA}_{\mathrm{ma}}$ by $10.41 \%$ compared to the control (B0). The content of macro-aggregates increased, while at the same time the content of water-stable micro-aggregates ( $\mathrm{WSA}_{\mathrm{mi}}$ ) decreased with increasing rate of biochar or biochar with $\mathrm{N}$. The significant effect was found only in the B20 treatment, where the value of $\mathrm{WSA}_{\mathrm{mi}}$ was $29 \%$ lower than in the control. According to $\mathrm{Lu}$ et al. [2014] the addition of a high rate of biochar increased the content of $\mathrm{WSA}_{\mathrm{ma}}$ by $31 \%$ compared to the control. On the other hand, Zhang et al. [2015] stated that the application of biochar had no significant effect on the value of $\mathrm{WSA}_{\text {ma }}$. These results were obtained in the first year after the application of biochar. As Obia et al. [2016] wrote, a longer period was needed for the oxidation of applied biochar particles. The positive effect of fertilizer on soil aggregation has been proven in many studies [e.g. Chen et al. 2015; Wang et al. 2016; 2017]. Wang et al. [2014] found that $\mathrm{N}$ fertilization increased the content of macro-aggregates that were larger than $2 \mathrm{~mm}$ by $7 \%$ compared to the control. However, the content of smaller macro- aggregates did not increase. In addition, the effect of fertilization was induced by an increase of root biomass and fungal hyphae in these size groups of aggregates. It corresponds to the statement by Bronick and Lal [2005] that plant roots and fungal hyphae are very important attributes for macroaggregate formation. The mean weight diameter of aggregates gained by dry sieving (MWD) is a commonly used parameter to evaluate the stability of aggregates. It determines the representation of individual fractions of macro-aggregates and the extent of their stability [Amezketa 1999]. $\mathrm{MWD}_{\mathrm{d}}$ was not significantly altered by the application of biochar alone or biochar with $\mathrm{N}$ fertilizer in both rates of biochar and $\mathrm{N}$ fertilizer. Conversely, statistically significant changes were observed within the mean weight diameter of water-stable macroaggregates gained by wet sieving $\left(\mathrm{MWD}_{\mathrm{W}}\right)$. Compared to the controls, the value of this parameter increased after B20 treatment by $37.11 \%$ and after B20N240 treatment by $41.23 \%$. No significant effect of the B20N160 or B20N240 treatments on $M_{W W} D_{\text {WSA }}$ was observed. Next, the coefficient of vulnerability $(\mathrm{Kv})$ and the index of water-stable aggregates (Sw) were evaluated. The calculated values of $\mathrm{Kv}$ and $\mathrm{Sw}$ also confirmed that application of biochar and biochar with $\mathrm{N}$ had a beneficial effect on soil structure. The results showed that the fertilized treatments were characterized by a lower value of $\mathrm{Kv}$ and a higher value of $\mathrm{Sw}$ than the control. The higher rate of biochar decreased the value of $\mathrm{Kv}$ and increased value of Sw. However in the case of $\mathrm{Kv}$, the decrease was significant only with B20N240 treatment (by 43.09\%) compared to the control B0N240. In the case of Sw, a sig-

Table 3. Statistical evaluation of the soil structure parameters

\begin{tabular}{|c|c|c|c|c|c|c|}
\hline \multirow{2}{*}{ Treatments } & WSA $_{\text {ma }}$ & WSA $_{\text {mi }}$ & MWD $_{d}$ & MWD & \multirow{2}{*}{$K v$} & \multirow{2}{*}{ Kw } \\
\cline { 2 - 6 } & \multicolumn{2}{|c|}{$(\%)$} & \multicolumn{2}{|c|}{$(\mathrm{mm})$} & & \\
\hline B0 & $71.9 \pm 4.38^{\mathrm{a}}$ & $28.1 \pm 4.38^{\mathrm{b}}$ & $3.04 \pm 0.88^{\mathrm{a}}$ & $0.61 \pm 0.09^{\mathrm{a}}$ & $4.94 \pm 1.24^{\mathrm{a}}$ & $0.83 \pm 0.05^{\mathrm{a}}$ \\
\hline B10 & $78.3 \pm 7.33^{\mathrm{ab}}$ & $21.8 \pm 7.33^{\mathrm{ab}}$ & $3.02 \pm 0.76^{\mathrm{a}}$ & $0.86 \pm 0.20^{\mathrm{ab}}$ & $3.71 \pm 1.85^{\mathrm{a}}$ & $0.91 \pm 0.09^{\mathrm{ab}}$ \\
\hline B20 & $80.3 \pm 6.34^{\mathrm{b}}$ & $19.7 \pm 6.34^{\mathrm{a}}$ & $2.77 \pm 0.97^{\mathrm{a}}$ & $0.97 \pm 0.34^{\mathrm{b}}$ & $3.24 \pm 1.64^{\mathrm{a}}$ & $0.93 \pm 0.07^{\mathrm{b}}$ \\
\hline B0N160 & $71.3 \pm 9.11^{\mathrm{a}}$ & $28.7 \pm 9.11^{\mathrm{a}}$ & $2.67 \pm 0.46^{\mathrm{a}}$ & $0.69 \pm 0.25^{\mathrm{a}}$ & $4.31 \pm 1.72^{\mathrm{a}}$ & $0.83 \pm 0.11^{\mathrm{a}}$ \\
\hline B10N160 & $73.6 \pm 5.34^{\mathrm{a}}$ & $26.3 \pm 5.34^{\mathrm{a}}$ & $2.45 \pm 0.30^{\mathrm{a}}$ & $0.76 \pm 0.22^{\mathrm{a}}$ & $3.56 \pm 1.57^{\mathrm{a}}$ & $0.85 \pm 0.06^{\mathrm{a}}$ \\
\hline B20N160 & $79.3 \pm 10.94^{\mathrm{a}}$ & $20.7 \pm 10.94^{\mathrm{a}}$ & $2.74 \pm 0.47^{\mathrm{a}}$ & $0.93 \pm 0.35^{\mathrm{a}}$ & $3.47 \pm 1.75^{\mathrm{a}}$ & $0.92 \pm 0.13^{\mathrm{a}}$ \\
\hline B0N240 & $73.5 \pm 9.28^{\mathrm{a}}$ & $26.5 \pm 9.28^{\mathrm{a}}$ & $3.09 \pm 0.68^{\mathrm{a}}$ & $0.67 \pm 0.20^{\mathrm{a}}$ & $5.06 \pm 2.20^{\mathrm{b}}$ & $0.85 \pm 0.11^{\mathrm{a}}$ \\
\hline B10N240 & $75.3 \pm 9.43^{\mathrm{a}}$ & $24.7 \pm 9.43^{\mathrm{a}}$ & $2.77 \pm 0.38^{\mathrm{a}}$ & $0.80 \pm 0.31^{\mathrm{ab}}$ & $3.96 \pm 1.61^{\mathrm{ab}}$ & $0.87 \pm 0.11^{\mathrm{a}}$ \\
\hline B20N240 & $83.1 \pm 6.12^{\mathrm{a}}$ & $16.9 \pm 6.12^{\mathrm{a}}$ & $2.93 \pm 0.47^{\mathrm{a}}$ & $1.14 \pm 0.35^{\mathrm{b}}$ & $2.88 \pm 1.30^{\mathrm{a}}$ & $0.96 \pm 0.07^{\mathrm{a}}$ \\
\hline
\end{tabular}

Treatments are stated in Material and methods. Different letters $(\mathrm{a}, \mathrm{b}, \mathrm{c})$ between lines indicate that treatment means are significantly different at $\mathrm{P}<0.05$ according to LSD test.

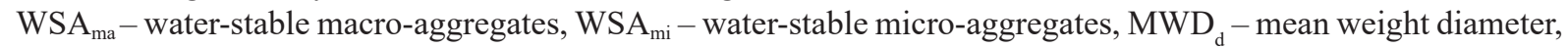
$\mathrm{MWD}_{\mathrm{W}}$ - mean weight dimeter of water-stable aggregates, $\mathrm{Kv}$ - coefficient of vulnerability, Sw - index of waterstable aggregates. 
nificant increase was observed in B20 (by 10.75\%) compared to B0. The positive effect of biochar on soil aggregation has been demonstrated by several studies [Lu et al. 2014; Germida 2015; Obia et al. 2016; Sing and Cowie 2014]. Biochar can affect aggregation via many mechanisms. First, Glaser et al. [2002] pointed at the bonding of applied particles of biochar with soil particles by the carboxyl and hydroxyl groups that are present on the surface of biochar. Next, the biochar also increases the hydrophobicity of soil particles that results in the increase of aggregate stability [Lu et al. 2014]. Biochar promotes the development of soil microorganisms via various mechanisms, thereby; it also contributes to the increased formation and the stability of aggregates [Lehmann et al. 2011].

The correlations between the evaluated parameters of soil structure and soil organic matter are shown in Table 4. The organic matter is a key element in stabilizing soil aggregates. The dynamics of SOM is related to the formation and disintigration of macro-aggregates [Six et al. 2000]. The beneficial effect of SOM on the formation and stabilization of aggregates has been demonstrated in studies by several authors [Six et al. 2002; Chaney and Swift, 1984; Spaccini et al., 2002]. In our study it was shown that $C_{\text {org }}$ and $C_{L}$ had a strong relationship with the majority of soil structure parameters $\left(\mathrm{WSA}_{\text {ma }}, \mathrm{WSA}_{\mathrm{mi}}, \mathrm{MWD}_{\mathrm{w}}, \mathrm{Kv}\right.$ and $\mathrm{Sw}$ ). Both of these quantitative parameters of SOM correlated positively with $\mathrm{WSA}_{\mathrm{ma}}$ and negatively with $\mathrm{WSA}_{\text {mi. }}$. For example, Burreto et al. [2009] found a positive relationship between the content of organic carbon and the shares of macro-aggregates. Next, the relationship between $\mathrm{C}_{\mathrm{L}}$ and $\mathrm{WSA}_{\mathrm{ma}}$ has confirmed the results of other studies [Polláková et al. 2017; Šimanský et al. 2016]. An increase of macro-aggregate stability and a higher content $\mathrm{C}_{\text {org }}$ and $\mathrm{C}_{\mathrm{L}}$ was also confirmed by their positive correlation with $\mathrm{MWD}_{\mathrm{W}}$ and $\mathrm{Sw}$ but it had a negative correlation with $\mathrm{Kv}$. At the same time, we con- cluded that the humic substances did not participate in the stabilization of macro-aggregates. The negative correlation of $\mathrm{C}_{\mathrm{HS}}$ with $\mathrm{WSA}_{\mathrm{ma}}$ and positive correlation of $\mathrm{WSA}_{\mathrm{mi}}$ were found. In addition, significant negative correlations of $\mathrm{MWD}_{\mathrm{w}}$ with $\mathrm{C}_{\mathrm{HA}}$ and $\mathrm{C}_{\mathrm{FA}}$ were demonstrated. When it comes to the $\mathrm{C}_{\mathrm{HA}}: \mathrm{C}_{\mathrm{FA}}$, no significant relationship with any parameters of soil structure was shown. $\mathrm{Q}_{\text {HA }}$ was in a negative correlation with $\mathrm{Kv}$.

\section{CONCLUSION}

Biochar improved the quantitative parameters of SOM. The content of $\mathrm{C}_{\text {org }}$ increased with the rate of biochar, after the application of biochar alone or in combination with a lower rate of $\mathrm{N}$. The values of $\mathrm{C}_{\mathrm{L}}, \mathrm{C}_{\mathrm{HA}}: \mathrm{C}_{\mathrm{FA}}, \mathrm{Q}_{\mathrm{HS}}$ and $\mathrm{Q}_{\mathrm{HA}}$ were not significantly altered by the addition of either biochar or $\mathrm{N}$ fertilizer. The values of $\mathrm{C}_{\mathrm{HS}}, \mathrm{C}_{\mathrm{HA}}$ and $\mathrm{C}_{\mathrm{FA}}$ were simultaneously reduced with biochar in rate of $20 \mathrm{t} \cdot \mathrm{ha}^{-1}$ with $160 \mathrm{~kg} \mathrm{~N} \cdot \mathrm{ha}^{-1}$ and biochar in both rates with $240 \mathrm{~kg} \mathrm{~N} \cdot \mathrm{ha}^{-1}$.

The results of our study confirmed the positive effect of biochar application on all evaluated parameters of soil structure, except $\mathrm{MWD}_{\mathrm{d}}$. The higher dose of biochar, the better the soil structure was. It resulted in the higher values of $\mathrm{WSA}_{\mathrm{ma}}, \mathrm{MWD}_{\mathrm{W}}$ and $\mathrm{Sw}$ and in the lower values of $\mathrm{WSA}_{\mathrm{mi}}$ and $\mathrm{Kv}$. None of the rates of biochar with $160 \mathrm{~kg} \mathrm{~N} \cdot \mathrm{ha}^{-1}$ had a significant effect on the parameters of soil structure. Biochar application with higher rate of $\mathrm{N}$ resulted in higher values of $\mathrm{WSA}_{\mathrm{ma}}$ and $\mathrm{MWD}_{\mathrm{W}}$ and lower value of vulnerability of soil structure.

The results showed that $\mathrm{C}_{\text {org }}$ and CL positively correlated with $\mathrm{WSA}_{\mathrm{ma}}, \mathrm{MWD}_{\mathrm{w}}, \mathrm{Sw}$ and negatively with $\mathrm{WSA}_{\mathrm{mi}}$ and $\mathrm{Kv}$. $\mathrm{C}_{\mathrm{HS}}$ had a significantly positive relationship with $\mathrm{WSA}_{\mathrm{mi}}$ and a negative relationship with $\mathrm{WSA}_{\mathrm{ma}}, \mathrm{MWD}_{\mathrm{W}}$ and Sw. $\mathrm{C}_{\mathrm{HA}}$ and $\mathrm{C}_{\mathrm{FA}}$ negatively correlated with $\mathrm{MWD}_{\mathrm{W}}$ and at the same time the $\mathrm{Q}_{\mathrm{HA}}$ negatively correlated with $\mathrm{MWD}_{\mathrm{d}}$ and $\mathrm{Kv}$.

Table 4. The values of correlation coefficients between the parameters of soil organic matter and soil structure

\begin{tabular}{|c|c|c|c|c|c|c|}
\hline Parameters & $\mathrm{WSA}_{\mathrm{ma}}$ & $W_{S A}$ & MWD & $\mathrm{MWD}_{\mathrm{w}}$ & $\mathrm{Kv}$ & Sw \\
\hline $\mathrm{C}_{\text {org }}$ & $0.295^{*}$ & $-0.295^{*}$ & n.s. & $0.353^{* *}$ & $-0.377^{\star *}$ & $0.298^{*}$ \\
\hline$C_{L}$ & $0.396^{* *}$ & $-0.396^{* *}$ & n.s. & $0.432^{\star * *}$ & $-0.433^{* * *}$ & $0.395^{* *}$ \\
\hline $\mathrm{C}_{\mathrm{HS}}$ & $-0.276^{*}$ & $0.276^{*}$ & n.s. & $-0.374^{* *}$ & n.s. & $-0.276^{*}$ \\
\hline $\mathrm{C}_{\mathrm{HA}}$ & n.s. & n.s. & n.s. & $-0.288^{*}$ & n.s. & n.s. \\
\hline $\mathrm{C}_{\mathrm{FA}}$ & n.s. & n.s. & n.s. & $-0.314^{*}$ & n.s. & n.s. \\
\hline $\mathrm{C}_{\mathrm{HA}}: \mathrm{C}_{\mathrm{FA}}$ & n.s. & n.s. & n.s. & n.s. & n.s. & n.s. \\
\hline $\mathrm{QHS}_{\mathrm{HS}}$ & n.s. & n.s. & n.s. & n.s. & n.s. & n.s. \\
\hline$Q_{H A}$ & n.s. & n.s. & $-0.463^{* * *}$ & n.s. & $-0.359^{* *}$ & n.s. \\
\hline
\end{tabular}

$\mathrm{n}=54 ; * * *=\mathrm{P} \leq 0.001 ; * *=\mathrm{P} \leq 0.01 ; *=\mathrm{P} \leq 0.05 ;$ n.s. $=\mathrm{P}>0.05$. 


\section{Acknowledgments}

This study was supported by the Slovak Grant Agency VEGA, No. 1/0604/16 and No. 1/0136/17, KEGA, No. 026SPU-4/2017 and Slovak Research and Development Agency under the contract No. APVV-15-0160.

\section{REFERENCES}

1. Abel S., Peters A., Trinks S., Schonsky H., Facklam M., Wessoiek G. 2013. Impact of biochar and hydrochar addition on water retention and water repellency of sandy soil. Geoderma, 202-203, 183-191.

2. Ahmad M., Rajapaksha A.U., Lim J.E., Zhang M., Bolan N., Mohav D., Vithanage M., Lee S.S., Ok Y.S. 2014. Biochar as a sorbent for contaminant management in soil and water. A review. Chemosphere, 99, 19-33.

3. Amezketa E. 1999. Soil aggregate stability: a review. Journal of Sustainable Agriculture, 14, 83-151.

4. Blaud A., Chevallier T., Virto I., Pablo A.L., Chenu C., Brauman A. 2014. Bacterial community structure in soil microaggregates and on particulate organic matter fractions located outside on inside soil macroaggregates. Pedopshere, 57, 191-194.

5. Bossuyt H., Six J., Heudrix P.F. 2004 Protection of soil carbon by microaggregates within earthworm casts. Soil Biology and Biochemistry, 37, 251-258.

6. Bronick C.J., Lal R. 2005. The soil structure and land management: a review. Geoderma, 124, 3-22.

7. Burreto R.C., Madari B.E., Maddock J.E.L., Machado L.O.A., Torres E., Frauchini J., Costa A.R. 2009. The impact of soil management on aggregation, carbon stabilization and carbon loss as $\mathrm{CO}_{2}$ in the surface layer of a Rhodic Ferralsol in Southern Brazil. Agricutural Ecosystem and Environment, 132, 243-251.

8. Dziadowiec H., Gonet S.S. 1999a. Estimation of soil organic carbon by Tyurin's method. Methodical guide-book for soil organic matter studies, 120, 7-8 (in Polish).

9. Dziadowiec H., Gonet S.S. 1999b. Estimation of fractional composition of soil humus by KononovaBielcikova's method. Methodical guide-book for soil organic matter studies, 120, 31-34, (in Polish).

10. Chaney K., Suift R.S. 1984. The influence of organic matter on aggregate stability in some British soils. European Journal of Soil Science, 35, 223-230.

11. Chaplot V., Cooper M. 2015. Soil aggregate stability to predict organic carbon outputs from soils. Geoderma, 243-244, 205-213.

12. Chen X., Li Z., Liu M., Jiang Ch., Che Y. 2015. Microbial community and functional diversity associated with different aggregate fractions of a paddy soil fertilized with organic manure and/or NPK fertilizer for 20 years. Journal of Soil and Sedimens, 15, 292-301.

13. Germida J., Gupta V.S.R. 2015. Soil aggregation: Influence on microbial biomass and application of biological process. Soil Biological and Biochemistry, 80, A3-A9.

14. Glaser B., Lehmann J., Zech W. 2002. Ameliorating physical and chemical properties of highly weathered soils in the tropic with charcoal- a review. Biology and Fertility of Soils, 35, 219-230.

15. Fischer D., Glaser B. 2012. Synergisms between compost and biochar for sustainable soil amelioration. In: Kumar S. (Ed), Management of Organic Waste, Tech Europe, Rijeka, pp. 167-198.

16. Hraško J., Červenka L., Facek Z., Komár J., Něměček J., Pospíšil J., Sirový V. 1962. Soil analyses. SVPL, Bratislava, (in Slovak).

17. Hussian M., Farooq M., Nawaaz A., Sadi A.M., Salaiman Z.M., Algmandi S.S., Amyara U., Ok Y.S., Siddique K.H.M. 2016. Biochar for crop production: potential benefits and risks. Journal of Soils and Sediments, 17, 685-716.

18. Jiang K., Xu Q.F. 2006. Abundance and dynamics of soil labile carbon pools under different types of forest vegetation. Pedosphere, 16, 505-511.

19. Jindo K., Sonoki T., Matsumoto K., Canellas L., Roig A., Sanchez-Monedero M.A. 2016. Influence of biochar addition on the humic substances of composting manures. Waste Management, 49, 545-552.

20. Joseph S.D., Arbestain M.C., Lin Y., Munroe P., Chia C.H., Hook J., Zwieten L., Kimber S., Cowie A., Singht B.P., Lehmenn J., Foidl N., Smernik R.J., Amonette, J.E. 2009. An investigation into the reaction of biochar in soil. Australian Journal of Soil Research, 48, 501-505.

21. Lehmann J., Rilling M., Thies J., Masiello C.A., Hockadaj W.C., Crowley D. 2011. Biochar effect on soil biota - A review. Biology and Biochemistry, 43, 1812-1836.

22. Liu X., Chen X., Jing Y., Li Q., Zhang J., Huang Q. 2014. Effect of biochar amendment on rapessed and swelt polutor yields and water stable aggregates in upland red soil. Catena, 123, 45-51.

23. Loginow W., Wisniewski W., Gonet S.S., Ciescinska B. 1987. Fractionation of organic carbon based on susceptibility to oxidation. Polish Journal of Soil Science, 20, 47-52.

24. Lu S.G., Sun F.F., Zono Y.T. 2014. Effect of rice hust biochar and coal fly ash on some physical properties of expansive clayey soil (Vertisol). Catena, 114, 37-44.

25. Mavi M.S., Singh G., Singh B.P., Serhon B.S., Choudrary O.P., Sagi S., Berry R. 2018. Interactive effects of rice-residue biochar and $\mathrm{N}$-fertilizer on 
soil structure functions and crop biomass in contrasting soils. Journal of Soil Science and Plant Nutrition, 107, 718-729.

26. Mukome F.N.D., Parikh S.J. 2015. Chemical, physical and surface characterization of biochar. In: Ok Y.S., Uchimiya M.S., Chang S.X., Blan N. (Eds), Biochar: production, characterization and application. CRC Press/Taylor and Francis Group, pp 400-407.

27. Oades J.M. 1993. The role of biology in the formation, stabilization and degradation of soil structure. Geoderma, 56, 377-400.

28. Obia A., Mulder J., Martines V., Conrelissen G., Borresen T. 2016. In situ effects of biochar on aggregation, water retention and porosity in lighttextured tropical soils. Soil and Tillage Research, 155, 35-44.

29. Omondi M.O., Xia X., Nahayo A., Liu X., Kora P.K., Pan G. 2016. Quantification of biochar effects on soil hydrological properties using meta-analysis of literature data. Geoderma, 274, 28-34.

30. Parakayastha T.J., Kumari S., Pathak H. 2015. Characterisation, stability, and microbial effect of four biochars produced crop residues. Geoderma, 239-240, 293-303.

31. Polláková N., Šimanský V., Kravka M. 2017. The influence of soil organic matter fractions in aggregates stabilization in agricultural and forest soils of selected Slovak and Czech hilly lands. Journal of Soils and Sediment, 18(8), 2790-2800.

32. Rutkowska A., Pikula D. 2013. Effect of crop rotation and nitrogen fertilization on the quality and quantity of soil organic matter. Quality Assessment, 25, 249-257.

33. Sainju U.M., Tonthan T.C., Lenssen A.W., Evans R.K. 2009. Tillage and cropping sequence impacts on nitrogen cycling in dryland farming in eastern Montana, USA. Soil and Tillage Research, 103, 332-341.

34. Scott H.D. 2000. Soil physics: agriculture and environmental application. Wiley-Blackwell, London.

35. Šimanský V., Horák J., Igaz D., Jonczak J., Markiewicz M., Felber R., Rizmiya E.Y., Lukac M. 2016. How dose of biochar and biochar with nitrogen can improve the parameters of soil organic matter and soil structure? Biologia, 71, 989-995.

36. Singh B.P., Cowie A.L. 2014. Long-term influence of biochar on native organic carbon mineralisation in carbon clayey soil. Scientific Reports, 4, 1-9.

37. Six J., Caunt R.T., Paustian K., Paulie A. 2002. Stabilization mechanisms of soil organic matter: Implications for C-saturation of soils. Plant and Soil, 241, 155-176.

38. Six J., Elliot E.T., Paustian K. 2000. Soil macroaggregates turnover and microaggregates formation: a mechanism for $\mathrm{C}$ sequestration under no-tillage agriculture. Soil Biology and Biochemistry, 32, 2099-2103.

39. Spaccini R., Piccolo A., Conte P., Haberhauder G., Gerzabek M.H. 2002. Increased soil organic carbon sequestration through hydrophobic production by humic substances. Soil Biology and Biochemistry, 34, 1839-1851.

40. Sun F., Lu S. 2014. Biochars improve aggregate stability, water retention and pore-space properties of clayey soil. Journal of Plant Nutrition and Soil Science, 177, 26-33.

41. Tisdall J.M. 1996. Formation of soil aggregates and accumulation of soil organic matter. In: Carter M.R., Steward B.A. (Eds), Structure and organic matter storage in agricultural soils, Boca Raton, CRC/Leuis Publisher, 481-487.

42. Valla M., Kozák J., Ondáček V. 2000. Vulnerability of aggregates separated from selected anthrosols developed on reclaimed dumpsites. Rostlinna Vyroba, 46, 563-568.

43. Wang D., Fonte S.J., Parikh S.J., Six J., Scow K.M. 2017. Biochar additions can enhance soil structure and the physical stabilization of $\mathrm{C}$ in aggregates. Geoderma, 303, 110-117.

44. Wang J., Xiong Z., Kozyakov Y. 2016. Biochar stability in soil ultra-analysis of composition and primming effect. Bioenergy, 8, 512-513.

45. Wang Y., Wang Z.L., Zhang Q., Hu N., Li Z., Lou Y., Li Y., Xue D., Chen Y., Wu Ch., Zou Ch.B., Kuzyakov Y. 2018. Long-term effects of nitrogen fertilization on aggregation and localization of carbon, nitrogen and microbial activities in soil. Science of the Total Environment, 624, 1113-1139.

46. Yan D., Wang D., Yang L. 2007. Long-term effect of chemical fertilizer, straw, and manure on labile organic matter fractions in a paddy soil. Biology and Fertility of Soils, 44, 93-101.

47. Zhang Q., Du Z.L., Lou Y., Me X. 2015. A oneyear short-term biochar application improved carbon accumulation in large macroaggregate fractions. Catena, 127, 26-31.

48. Zhang Q., Worsnop D.R., Canagaratha M.R., Jimenez J.L. 2005. Hydrocarbon-like and oxygenated organic aerosoils in Pittsburgh: insights into sources and processes of organic aerosols. Atmospheric Chemistry and Physics, 5, 3289-3311.

49. Zhao S., Ta N., Li Z., Yang Y., Zhang X., Liu D., Zhang A., Wang X. 2017. Varying pyrolysis temperature impacts application effects of biochar on soil labile organic carbon and humic substances. Applied Soil Ecology, 116, 399-409.

50. Zlielinska A., Olesczuk P., Charmas B., Zieba J.S., Pasieczua-Patkowska S. 2015. Effect of sewage sludge properties on the biochar characteristic. Journal of Analyticall and Applies Pyrolysis, 112, 201-213. 